Volume 1 Issue 2, September 2016: pp. 141-149. Copyright @ LamLaj. Faculty of Law, Lambung Mangkurat University, Banjarmasin, South Kalimantan, Indonesia. ISSN: 2502-3136 | e-ISSN: 2502-3128. Open Access at: http://lamlaj.unlam.ac.id

\title{
Kedudukan Basyarnas Dalam Penyelesaian Sengketa Perbankan Syariah (Studi Putusan Mahkamah Konstitusi Nomor 93/Puu-X/2012)
}

\author{
Ridzky Adityanto \\ Program Magister Kenotariatan Fakultas Hukum Universitas Lambung Mangkurat. \\ Jl.Brigjen H. Hasan Basri Komplek Unlam. Banjarmasin.70123 Indonesia. \\ Telp/Fax: +62 511 3307877.E-mail: ridzky.adityanto@yahoo.com
}

Diterima: 25/7/2016; Revisi: 16/09/2016; Disetujui: 19/09/2016

\begin{abstract}
The subject of the research in this thesis is focused on sharia arbitration principle in settling sharia banking disputes. The study was conducted after Law No. 21 of 2008 concerning Sharia Banking (UUPS 2008) provided the choice of forum for sharia banks and their clients to settle their disputes through sharia arbitration. The choice of forum is done through an agreement which is formulated in contracts. Even though the Ruling of the Constitutional Court No. 93/PUU-X/2012 has stated that the explanation of Article 55, paragraph (2) of UUPS/2008 does not have any binding legal force, the validity of sharia arbitration as the choice of forum can always be used in settling sharia banking disputes. In accordance with the norms formulated in Article 55, paragraph (2) of UUPS/2008, sharia arbitration as the choice of forum outside the religious court is allowed to settle sharia banking disputes when there is a written agreement among the conflicting parties, there was the principle deity in it, arbitration agreement became the basic authority of sharia arbitration, reconciliation was the objective of settling a dispute through sharia arbitration in order to maintain good relationship among the conflicting parties, the ruling of sharia arbitration was final and binding; arbitrators were non-aligned and Muslims; and lastly, there was confidential principle in it.
\end{abstract}

Keywords: Sharia Arbitration Board Nation and Sharia banking Dispute

Abstrak: Subyek penelitian dalam tesis ini difokuskan pada prinsip arbitrase syariah dalam menyelesaikan sengketa perbankan syariah. Penelitian dilakukan setelah UU No. 21 Tahun 2008 tentang Perbankan Syariah (UUPS 2008) tersedia pilihan forum bagi bank syariah dan klien mereka untuk menyelesaikan perselisihan mereka melalui arbitrase syariah.Pilihan forum dilakukan melalui kesepakatan yang dirumuskan dalam kontrak. Meskipun Putusan Mahkamah Konstitusi Nomor 93 / PUU-X/2012 telah menyatakan bahwa penjelasan Pasal 
55 ayat (2) dari UUPS / 2008 tidak memiliki kekuatan hukum mengikat, validitas arbitrase syariah sebagai pilihan dari forum dapat selalu digunakan dalam menyelesaikan sengketa perbankan syariah. Sesuai dengan norma-norma yang dirumuskan dalam Pasal 55 ayat (2) dari UUPS / 2008, arbitrase syariah sebagai pilihan forum di luar pengadilan agama diperbolehkan untuk menyelesaikan sengketa perbankan syariah ketika ada perjanjian tertulis antara pihak yang berkonflik, ada dewa prinsip di dalamnya, perjanjian arbitrase menjadi kewenangan dasar arbitrase syariah, rekonsiliasi adalah tujuan menetap sengketa melalui arbitrase syariah untuk menjaga hubungan baik antara pihak yang berkonflik, putusan arbitrase syariah adalah final dan mengikat ;, arbiter adalah non-blok dan Muslim; dan terakhir, ada prinsip rahasia di dalamnya.

Kata kunci: Syariah Badan Arbitrase Bangsa dan Sengketa perbankan Syariah

\section{PENDAHULUAN}

Salah satu pioner dari berjalannya sistem ekonomi Islam di negara ini dapat dilihat dari perkembangan perbankan syariah sebagai bagian dari sistem ekonomi Islam sejak tahun 1998 sampai dengan sekarang. Walaupun disbandingkan dengan negara lainnya kemunculan perbankan syariah di Indonesia agak terlambat namun perkembangan yang di dapat oleh perbankan syariah begitu signifikan. ${ }^{1}$.

Diberlakukannya Undang-Undang Nomor 7 Tahun 1992 tentang Perbankan tanggal 25 Maret 1992, menandai adanya kesepakatan rakyat dan bangsa Indonesia untuk menerapkan Dual Banking System, atau sistem perbankan ganda di Indonesia. Perbankan Syariah semakin marak manakala diterbitkannya UndangUndang No. 10 Tahun 1998 tentang Perubahan atas Undang-Undang Nomor 7 Tahun 1992 tentang Perbankan (Lembaran Negara Republik Tahun 1998 Nomor 182, Tambahan Lembaran Negara Republik Indonesia Nomor 3790, untuk selanjutnya disebut UU 10/1998) yang memungkinkan perbankan menjalankan

1 Muhammad Iqbal. 29 Agustus 2013. Implikasi Hukum Terbitnya Putusan Mahkamah Konstitusi Nomor 93/PUU-X/2012. dual banking system atau Bank Konvensional dapat mendirikan Divisi Syariah. ${ }^{2}$

Perbankan berbasis syari'ah telah mengalami perkembangan yang pesat Kontribusi keuangan syari'ah memang masih kecil dibanding dengan dominasi konvensional. Namun tak dapat dipungkiri tingkat pertumbuhannya amat pesat bukan hanya di bidang perbankan, bisnis berbasis ekonomi syari'ah juga telah memasuki wilayah asuransi, pegadaian, reksa dana dan lain-lain. Melihat kian luas dan beragamnya pola bisnis berbasis syari'ah maka aspek perlindungan hukumnya menjadi penting diupayakan keberadaannya. ${ }^{3}$

Pelaku dan pengguna jasa perbankan syari'ah harus menjalankan kegiatannya berdasarkan syari'ah. Bila terjadi perselisihan pendapat baik dalam penafsiran maupun dalam pelaksanaan isi perjanjian, kedua belah pihak akan berusaha menyelesaikannya secara musyawarah, meski demikian masih ada kemungkinan perselisihan tidak dapat diselesaikan secara musyawarah. Kemungkinan seperti ini kian besar, terlebih dalam

2 Wirdyaningsih. 2005. Bank Dan Asuransi Islam Di Indonesia. Jakarta: Kencana, hlm 1.

3 Ibid. hlm. 6. 
kehidupan dunia ekonomi syari'ah yang kian beragam. ${ }^{4}$

Sebelum hadirnya UU 50/2009, kasus sengketa perbankan syari'ah tidak bisa diselesaikan di pengadilan agama. Yang menjadi sebab, karena wewenang pengadilan agama telah dibatasi UU 7/1989, yang hanya dapat memeriksa dan mengadili perkaraperkara di luar kelima bidang tersebut. Di sisi lain, pengadilan negeri juga tidak pas untuk menangani kasus sengketa lembaga keuangan syari'ah. Pasalnya, bagaimanapun lembaga ini memiliki dasar-dasar hukum penyelesaian perkara yang berbeda dengan yang dik-ehendaki pihak-pihak yang terikat dal-am akad syari'ah.

Dalam hal implementasi, para pelaku dan pengguna jasa perbankan syari'ah harus menjalankan kegiatannya berdasarkan syari'ah.Pola hubungan yang didasarkan pada keinginan untuk menegakkan sistem syari'ah diyakini sebagai pola hubungan yang kokoh antara bank dan nasabah. Bila terjadi perselisihan pendapat, baik dalam penafsiran maupun dalam pelaksanaan isi perjanjian, kedua pihak akan berusaha menyelesaikan secara musyawarah. Meski demikian, masih ada kemungkinan perselisihan itu tidak dapat diselesaikan secara musyawarah.Kemungkinan seperti ini kian besar, terlebih dalam kehidupan dunia ekonomi syari'ah yang kian beragam.

Masalah hukum atau isu hukum kemudian mencuat ketika terdapat kekaburan hukum (vage norm) berkaitan dengan pengaturan sengketa perbankan syariah nasional yang telah mendapat putusan dari Basyarnas yang bersifat konkrit, final dan mengikat tetap memerlukan peran Pengadilan Agama yang bertugas dan berwenang memeriksa, memutus,

$4 \quad$ Ibid dan melakukan eksekusi serta menyelesaikan perkara di tingkat pertama antara orang-orang yang beragama Islam di bidang perbankan syariah nasional.

Salah satu masalah hukum atau isu hukum yang dianggap sebagai kekaburan hukum adalah terdapat dalam Pasal 55 ayat (1), (2) dan (3) Un-dang-Undang Nomor 21 Tahun 2008 tentang Perbankan Syariah (Lembaran Negara Republik Tahun 2008 Nomor 94, Tambahan Lembaran Negara Republik Indonesia Nomor 3780, untuk selanjutnya disebut UU 21/2008) beserta dengan Penjelasan Pasal 55 ayat (2) UU 21/2008.

Ketidakjelasan atau kekaburan hukum (vage norm) dari ketentuan Pasal 55 ayat (1), (2) dan (3) UU 21/2008, tersebut di atas sangat jelas terlihat, bahwa pada ayat (1) menyatakan bahwa penyelesaian sengketa perbankan syariah dapat dilakukan dilakukan oleh Pengadilan dalam lingkup Peradilan Agama, akan tetapi dalam ayat (2) UU 21/2008 menyatakan lain lagi bahwa dalam hal para pihak telah memperjanjikan penyelesaian sengketa selain sebagaimana dimaksud pada ayat (1), penyelesaian dapat dilakukan sesuai dengan isi akad, yaitu bahwa dalam Pasal 55 ayat (2) UU 21/2008 justru membuka peluang untuk diselesaikannya penyelesaian sengketa perbankan syariah melalui penyelesaian sengketa di luar pengadilan salah satunya adalah melalui arbitrase dan Mengenyampingkan kewenangan Pengadilan Agama dalam penyelesaian sengketa perbankan syariah sebagaimana ditegaskan dalam Pasal 55 ayat (1) UU 21/2008.

Berkenaan dengan pelaksanaan putusan Basyarnas adalah bahwa dalam perkembangannya Mahkamah Konstitusi telah menerbitkan suatu putusan mengenai permohonan peninjauan peraturan perundang-undangan 
(Judisi-al Review) terhadap Pasal 55 ayat (1), (2) dan (3) beserta penjelasan Pasal 55 ayat (2) UU 21/2008, mengenai kekuatan hukum putusan Basyarnas yang dapat dibatalkan melalui permohonan pembatalan putusan Basyarnas oleh pihak yang dirugikan kepada Pengadilan Agaman. Hal tersebut kemudian dijawab dengan Putusan Mahkamah Konstitusi Nomor 93/PUU-X/2012, yang diucapkan pada kamis tanggal 29 Agustus 2013, perihal uji materi terhadap UU 21/2008, yang salah satu amar putusannya pada point 1.1 dan 1.2 menyatakan: "Penjelasan Pasal 55 ayat (2) UU 21/2008 dianggap bertentangan dengan Undang-Undang Dasar 1945 dan tidak mempunyai kekuatan hukum lagi”.

Dengan demikian sangatlah jelas bahwa kedudukan putusan Basyarnas dalam menyelesaikan sengketa perbankan syariah diperlukan kajian yuridis yang mendalam untuk memberikan kejelasan dan pencerahan yang tepat dalam masalah ini, dengan kata lain putusan Basyarnas dalam menyelesaikan sengketa perbankan syariah masih bersifat kabur secara hukum dan diperlukan pengaturan yang lebih sempurna dan lengkap serta jelas dan tegas mengenai pelaksanaan putusan Basyarnas dalam menyelesaikan sengketa bisnis syariah.

\section{METODE PENELITIAN}

Penelitian ini merupakan jenis penelitian hukum normatif, yaitu merupakan penelitian hukum yang dilakukan dengan cara meneliti dan menggunakan bahan hukum yaitu bahan hukum primer, bahan hukum sekunder bahan hukum tersier yang didapat dari penelitian kepustakaan (library research). Tipe penelitian ini mengenai hal kekaburan hukum (Vage Norm), yaitu aturan dari peraturan perundang- undangan dari pokok permasalahan sudah ada namun belum jelas. ${ }^{5}$

Adapun mengenai hal kekaburan hukum (Vage Norm), terdapat dalam Pasal 50 ayat (1), (2) dan (3) serta penjelasan Pasal 55 ayat (2) UU 21/2-008 yang masih belum jelas dan tegas mengatur mengenai kewenangan Basyarnas dalam menyelesaikan sengketa perbankan syariah setelah lahirnya Putusan Mahkamah Konstitusi Nomor 93/PUU-X/2012 dan pelaksanaan eksekusi putusan Basyarnas dalam menyelesaikan sengketa perbankan syariah setelah lahirnya Putusan Mahkamah Konstitusi Nomor 93/PUU-X/2012.

Dalam penelitian ini menggunakan pendekatan peraturan perundang-undangan (Statute Approach).Dalam metode pendekatan perundang-undangan peneliti perlu memahami hirarki dan asas-asas dalam peraturan perundang-undangan, atau produk yang merupakan beschikking/decree yaitu suatu keputusan yang diterbitkan oleh pejabat administrasi yang bersifat konkrit dan khusus. ${ }^{6}$

Dalam hal ini pendekatan dan analisis terhadap Pasal 50 ayat (1), (2) dan (3) serta penjelasan Pasal 55 ayat (2) UU 21/2008 mengenai kewenangan Basyarnas dalam menyelesaikan sengketa perbankan syariah setelah lahirnya Putusan Mahkamah Konstitusi Nomor 93/PUU-X/2012 dan pelaksanaan eksekusi putusan Basyarnas dalam menyelesaikan sengketa perbankan syariah setelah lahirnya Putusan Mahkamah Konstitusi Nomor 93/PUU-X/2012.

Penelitian ini juga menggunakan pendekatan konsep (conseptualapproach) yaitu

5 Soerjono Soekanto. 1986. Pengantar Penelitian Hukum. Jakarta: Universitas Indonesia Press, hlm. 32.

$6 \quad$ Ibid, hlm. 137 
manakala peneliti tidak beranjak dari aturan hukum yang ada. Hal itu dilakukan karena memang belum atau tidak ada aturan hukum untuk masalah yang dihadapi.Pendekatan konsep ini bersifat universal oleh karena itu penulis menelaah pandangan-pandangan sarjana hukum dari berbagai negara mengenai suatu masalah tersebut. ${ }^{7}$

\section{TEORI}

Dalam penulisan ini terdapat 2 teori hukum yaitu :

\section{Teori Penyelesaian Sengketa Di Luar Pengadilan}

Pada Bab I UU 30/199, menyatakan mengenai penyelesaian sengketa dimana para pihak telah memutus dari sejak awal bahwa dalam kesepakatan perjanjian mereka apabila terjadi sengketa, maka akan diselesaikan dengan cara arbitrase. Klausula perjanjian arbitrase tersebut menjadi bagian yang sah dari perikatan tersebut. Tetapi tidak tertutup kemungkinan bahwa penyelesaian sengketa dengan cara arbitrase dapat dipilih sesudah terjadinya sengketa di belakangan. Hal penting lainnya adalah pengakuan akan eksistensi dari akan dibentuknya suatu lembaga alternatif penyelesaian sengketa ${ }^{8}$

\section{Teori Perbankan Syariah}

Pasal 1 angka 1 UU 21/2008 disebutkan bahwa:" Perbankan Syariah adalah segala sesuatu yang menyangkut tentang Bank Syariah dan Unit Usaha Syariah, mencakup kelembagaan, kegiatan usaha, serta cara

\footnotetext{
$7 \quad$ Ibid

8 Moch. Faisal Salam. 2007. Penyelesaian Sengketa Bisnis Secara Nasional Dan Internasional. Bandung: Mandar Maju, hlm. 27
}

dan proses dalam melaksanakan kegiatan usahanya". 9

Pasal 1 angka 4 UU 21/2008 menyebutkan bahwa: "Bank Konvensional adalah Bank yang menjalankan kegiatan usahanya secara konvensional dan berdasarkan jenisnya terdiri atas Bank umum Konvensional dan Bank Perkreditan Rakyat". Sedangkan dalam Pasal 1 angka 7 UU 21/2008 disebutkan tentang pengertian bank syariah:" Bank Syariah adalah bank yang menjalankan kegiatan usahanya berdasarkan Prinsip Syariah dan menurut jenisnya terdiri atas Bank Umum Syariah dan Bank Pembiayaan Rakyat Syariah”.

Pengertian Bank Umum Syariah dijelaskan pada Pasal 1 angka 8 UU 21/2008 sedangkan Bank Pembiayaan Rakyat Syariah dijelaskan pada Pasal 1 angka 9 UU 21/2008. Yang disebut dengan Bank Umum Syariah adalah Bank Syariah yang dalam kegiatannya memberikan jasa dalam lalu lintas pembayaran, sedangkan pengertian Bank Pembiayaan Rakyat Syariah adalah Bank syariah yang dalam kegiatannya tidak memberikan jasa dalam lalu lintas pembayaran.

\section{ANALISIS DAN PEMBAHASAN}

Dasar hukum keputusan Badan Arbitrase Syariah Nasional (Basyarnas) dalam penye ${ }^{-}$ lesaian sengketa perbankan syariah, yaitu pada dasarnya dapat didasarkan pada ketentuan Pasal 55 UU 21/2008 yang menegaskan bahwa Bas-yarnas juga dapat menghasilkan putusan yang bersifat final dan mengikat (binding) sehingga tidak ada banding dan kasasi terhadap putusan tersebut. Kemudian berkaitan dengan permasalahan dasar hukum keputusan Badan Arbitrase Syariah Nasional (Basyarnas) dalam penyelesaian sengketa perbankan

9 Ibid, hlm. 64. 
syariah, pada dasarnya juga dapat didasarkan pada ketentuan Pasal 60 UU 30/1999, yang menyatakan bahwa "Putusan arbitrase bersifat final dan mempunyai kekuatan hukum tetap dan mengikat para pihak". Kedudukan keputusan Badan Arbitrase Syariah Nasional (Basyarnas) dalam penyelesaian sengketa perbankan syariah setelah diterbitkannya Putusan Mahkamah Konstitusi Nomor 93/ PUU-X/2012, maka kekuatan hukum untuk pelaksanaan surat keputusan Badan Arbitrase Syariah Nasional (Basyarnas) adalah sah dan mengikat para pihak serta bersifat final and binding berdasarkan asas "pactum compromitendo", hanya saja eksekusi atau pelaksanaan surat keputusan Badan Arbitrase Syariah Nasional (Basyarnas) menurut ketentuan Surat Edaran Mahkamah Agung Nomor 8 tahun 2008 tentang Eksekusi Putusan Badan Arbitrase Syariah dan ketentuan Pasal 55 UU 21/2008, hal ini dimaksudkan untuk menciptakan tertib hukum berkaitan dengan penyelesaian sengketa di bidang ekonomi dan perbankan syariah yang menjadi kewenangan Pengadilan Agama.

1Pelaksanaan surat Keputusan Badan Arbitrase Syariah Nasional (Basyarnas) dalam penyelesaian sengketa perbankan syariah setelah lahirnya putusan Mahkamah Konstitusi Nomor 93/PUU-X/2012, sangat memiliki keterkaitan dengan kewenangan Pengadilan Agama dalam pelaksanaan putusan Basyarnas yang didasari dengan Pasal 59-64 UU 30/1999 dan ketentuan Pasal 55 UU 21/2008 serta Pasal 54 UU 50/2009 yang menunjukkan bahwa pelaksanaan putusan Basyarnas dalam penyelesaian sengketa perbankan syariah memerlukan kewenangan Pengadilan Agama agar pelaksanaan Keputusan Basyarnas tersebut mempunyai kekuatan hukum tetap, hal tersebut dimaksudkan untuk mencapai keselarasan antara hukum materil yang berlandaskan prinsip-prinsip Islam dengan lembaga peradilan Agama yang merupakan representasi lembaga Peradilan Islam, dan juga selaras dengan para aparat hukumnya yang beragama Islam serta telah menguasai hukum Islam.

Dasar hukum pelaksanaan eksekusi putusan Basyarnas Dalam Menyelesaikan Sengketa Perbankan Syariah Setelah Lahirnya Mahkamah Konstitusi Nomor 93/ PUU-X/2012 adalah lahirnya Surat Edaran MA (SEMA) Nomor 8 Tahun 2010 yang mengatur eksekusi putusan badan arbitrase syariah nasional (basyarnas) yang menghendaki pelaksanaan eksekusi sengketa perbankan syariah Setelah Lahirnya Mahkamah Konstitusi Nomor 93/PUU-X/2012 adalah dilakukan oleh pengadilan dalam lingkungan Peradilan Agama.Kewenangan pengadilan agama dalam pelaksanaan eksekusi putusan Basyarnas mengenai sengketa perbankan syariah setelah lahirnya Mahkamah Konstitusi Nomor 93/PUU-X/2012, adalah selaras dengan ketentuan Pasal 49 UU 50/2009, yang telah menetapkan hal-hal yang menjadi kewenangan lembaga Peradilan Agama, yaitu memutus dan menyelesaikan perkara tertentu bagi yang beragama Islam dalam bidang perkawinan, waris, wasiat, hibah, wakaf, zakat, infaq, shadaqah dan ekonomi syari'ah. Dalam penjelasan undang-undang ini disebutkan bahwa yang dimaksud dengan ekonomi syari'ah adalah perbuatan atau kegiatan usaha yang dilaksanakan menurut prinsip syari'ah yang meliputi bank syari'ah, asuransi syari'ah, reasuransi syari'ah reksadana syari'ah, sekuritas syari'ah, pembiayaan syari'ah, pegadaian syari'ah, dan dana pensiun, lembaga keuangan syari'ah, dan lembaga keuangan 
mikro syari'ah yang tumbuh dan berkembang di Indonesia.

Hambatan yuridis dalam hal kewenangan pengadilan agama untuk melakukan eksekusi Putusan Basyarnas mengenai sengketa perbankan syariah setelah lahirnya putusan Mahkamah Konstitusi Nomor 93/PUU-X/2012, yaitu terdiri dari: a) Fatwa-fatwa Dewan Syari'ah Nasional (DSN), b) Aqad Perjanjian (Kontrak), c) Sumber Hukum Fiqih, d) Hukum Kebiasaan, dan e) Yurisprudensi Pengadilan Agama.

\section{PENUTUP}

1. Dasar hukum keputusan Basyarnas dalam penyelesaian sengketa perbankan syariah, yaitu pada dasarnya dapat didasarkan pada ketentuan Pasal 55 UU 21/2008 yang menegaskan bahwa Basyarnas juga dapat menghasilkan putusan yang bersifat final dan mengikat (binding) sehingga tidak ada banding dan kasasi terhadap putusan tersebut. Kedudukan keputusan Basyarnas dalam penyelesaian sengketa perbankan syariah setelah diterbitkannya Putusan Mahkamah Konstitusi Nomor 93/PUU-X/2012, maka kekuatan hukum untuk pelaksanaan surat keputusan Basyarnas adalah sah dan mengikat para pihak serta bersifat final and binding berdasarkan asas "pactum compromittendo”, serta pelaksanaan surat Keputusan Basyarnas dalam penyelesaian sengketa perbankan syariah setelah lahirnya putusan Mahkamah Konstitusi Nomor 93/PUU-X/2012,sangat memiliki keterkaitan dengan kewenangan Pengadilan Agama dalam pelaksanaan putusan Basyarnas yang didasari dengan Pasal 59-64 UU 30/1999 dan ketentuan Pasal 55 UU 21/2008 serta Pasal 54
UU 50/2009 yang menunjukkan bahwa pelaksanaan putusan Basyarnas dalam penyelesaian sengketa perbankan syariah memerlukan kewenangan Pengadilan Agama agar pelaksanaan Keputusan Basyarnas tersebut mempunyai kekuatan hukum tetap.

2. Sengketa Perbankan Syariah Setelah Lahirnya Mahkamah Konstitusi Nomor 93/PUU-X/2012 adalah lahirnya Surat Edaran MA (SEMA) Nomor 8 Tahun 2010 yang mengatur eksekusi putusan Basyarnas yang menghendaki pelaksanaan eksekusi sengketa perbankan syariah Setelah Lahirnya Mahkamah Konstitusi Nomor 93/PUU-X/2012 adalah dilakukan oleh pengadilan da-lam lingkungan Peradilan Agama hal tersebut adalah selaras dengan ketentuan Pasal 49 UU $50 / 2009$, yang telah menetapkan halhal yang menjadi kewenangan lembaga Peradilan Agama, yaitu memutus dan menyelesaikan perkara tertentu bagi yang beragama Islam dalam bidang perkawinan, waris, wasiat, hibah, wakaf, zakat, infaq, shadaqah dan ekonomi syari'ah. Hambatan yuridis dalam hal kewenangan pengadilan agama untuk melakukan eksekusi Putusan Basyarnas mengenai sengketa perbankan syariah setelah lahirnya putusan Mahkamah Konstitusi Nomor 93/ PUU-X/2012, yaitu terdiri dari: a)Fatwafatwa Dewan Syari'ah Nasional (DSN), b)Aqad Perjanjian (Kontrak), c)Sumber Hukum Fiqih, d)Hukum Kebiasaan, dan e)Yurisprudensi Pengadilan Agama 


\section{BIBLIOGRAFI}

\section{Literatur/Buku-Buku}

Al-Zarqa, Musthafa Ahmad. 1998. Peradilan Agama Dalam Meny-elesaikan Sengketa Syariah menurut Al Fi'il Al Dharr Al Dhaman Fih, Dar'al Qalam, Yogyakarta: Damaskus Pers.

Anshori, Abdul Ghofur. 2009. Hukum Perbankan Syariah (Undang-Undang No. 21 Tahun 2008), Bandung: PT. Refika Aditama.

Antonio, Muhammad Syafi'i. 2001. Bank Syari'ah, Dari Teori ke Praktek, Jakarta: Gema Insani Press.

Barkatullah, Abdul Halim. 2011. Hukum Lembaga Ekonomi Syariah di Indonesia, Bandung:Nusa Media.

Dirdjosisworo, Soedjono. 1994. Kejahatan Bisnis (Orientasi dan Konsepsi). Bandung: Penerbit Mandar Maju.

Ibrahim, Johannes. 2007. Bank sebagai Lembaga Intermediasi Dalam Hukum Positif. Bandung: CV. Utomo.

Kansil, CST. 1986. Pengantar Ilmu Hukum dan Tata Hukum Indonesia, Jakarta: Balai Pustaka.

Kasmir, 2005, Dasar-Dasar Perbankan, Jakarta: PT Raja Grafindo Persada.

Marzuki, Peter Mahmud. 2005. Penelitian Hukum. Jakarta: Prenada Media.

Salam, Moch. Faisal. 2007. Penyelesaian Sengketa Bisnis Secara Nasional Dan Internasional, Bandung: Mandar Maju.

Sumantoro. 1986. Hukum Ekonomi. Jakarta:Universitas Indonesia Pers.

Soekanto, Soerjono. 1986. Pengantar Penelitian Hukum. Jakarta: Universitas Indonesia Press.
Sumitro, Warkum. 1996. Perbankan Islam dan Lembaga-lembaga Terkait. Jakarta: Rajawali Pers.

Sudarsono, Budi. 2003, Bank dan Lembaga Keuangan Syariah, Yogy-akarta: Persada

Taufiq, 2006.Sumber hukum Ekonomi Syari'ah, Jakarta: UI Pers.

Wirdyaningsih, 2005, Bank Dan Asuransi Islam Di Indonesia, Jakarta: Kencana.

\section{Peraturan Perundang-undangan}

KUH Perdata (Staatsblad 1847 Nomor 23)

Undang-Undang Nomor 30 Tahun 1999 Tentang Alternatif Penyelesaian Sengketa Di Luar Pengadilan (Lembaran Negara Republik Tahun 1999 Nomor 138, Tambahan Lembaran Negara Republik Indonesia Nomor 3872)

Undang-undang Nomor 7 Tahun 1992 Sebagaimana diperbaharui UndangUndnag Nomor 10 tahun 1998 Tentang Perbankan (Lembaran Negara Republik Tahun 1998 Nomor 182, Tambahan Lembaran Negara Republik Indonesia Nomor 3790)

Undang-Undang Nomor 21 Tahun 20-08 tentang Perbankan Syariah (Lembaran Negara Republik Tahun 2008 Nomor 94, Tambahan Lembaran Negara Republik Indonesia Nomor 3780)

Undang-Undang Nomor 48 Tahun 2009 Tentang Kekuasaan Kehakiman (Lembaran Negara Republik Tahun 2009 Nomor 139, Tambahan Lembaran Negara Republik Indonesia Nomor 5034)

Undang-undang Nomor 50 Tahun 20-09 Tentang Perubahan Kedua atas Undangundang Nomor 7 Tahun 1989 Tentang Peradilan Agama (Lembaran Negara Republik Tahun 2009 Nomor 159, 
Tambahan Lembaran Negara Republik Indonesia Nomor 50-78)

Surat Edaran MA (SEMA) Nomor 8 Tahun 2010 tentang Pelaksanaan Eksekusi Putusan Basyarnas.

Keputusan Dewan Pimpinan Majelis Ulama Indonesia Nomor: Kep-09/MUI/XII/2003 tanggal 24 Desember 2003 Tentang Perubahan Lembaga Badan Arbitrase Muamalat Indonesia (BAMUI) diubah menjadi Badan Arbitrase Syari'ah Nasional (BASYARNAS)

Putusan Mahkamah Konstitusi Nomor 93/ PUU-X/2012

\section{Kamus/Internet}

Badudu, J. S. 1999. Kamus besar bahasa Indonesia, Jakarta: Pusta-ka Raya.

Anonim.http://www.mui.or.id/content/ sejarah-BASYARNAS, Sejarah Basyarnas, terakhir diakses pada tanggal 15 Agustus 2015.

Tim Publikasi. 2013. Kumpulan Penelitian Tesis. www.undip.ac.-id. Diakses tanggal 15 Agus-tus 2015.

Tim Publikasi. 2013. Kumpulan Tesis Pasca Sarjana. Sumber: ww-w.ui.ac.id. Diakses Tanggal 15 Agustus 2015 